\title{
IDENTIFIKASI TEKNOLOGI PENCEGAHAN PEMBENTUKAN BIOFILM DI PERMUKAAN SENSOR YANG DIGUNAKAN PADA TEKNOLOGI ONLIMO
}

\author{
Muhammad Haqqiyuddin Robbani, dan Heru Dwi Wahjono \\ Pusat Teknologi Lingkungan, BPPT, Kawasan Puspiptek, Tangerang Selatan, 15314, Indonesia \\ Email: muhammad.haqqiyuddin@bppt.go.id ; heru.dwi@bppt.go.id
}

\begin{abstract}
ABSTRAK
Salah satu permasalahan yang timbul selama proses penerapan teknologi online monitoring (Onlimo) adalah munculnya biofilm pada permukaan sensor multiprobe yang digunakan. Kehadiran biofilm ini dapat mengganggu performa sensor dalam melakukan pembacaan. Oleh karena itu diperlukan suatu kajian mendalam terkait metode dan teknologi yang dapat digunakan untuk mencegah munculnya biofilm pada permukaan sensor. Tulisan ini disusun berdasarkan kajian literatur dan hasil riset yang dilakukan oleh berbagai universitas dan lembaga penelitian baik diluar maupun dalam negeri, baik dalam skala laboratorium, bench, ataupun pilot-plant. Penggalian literatur meliputi proses pembentukan biofilm, identifikasi teknologi pencegahan pembentukan biofilm secara konvensional, serta identifikasi teknologi pencegahan pembentukan biofilm terkini. Tulisan ini diharapkan dapat menjadi informasi dan bahan rujukan dalam memilih teknologi yang tepat untuk diaplikasikan.
\end{abstract}

Kata kunci: biofilm, pemantauan online, sensor, teknologi pencegahan

\section{IDENTIFICATION OF BIOFILM FORMATION PREVENTION TECHNOLOGY ON SENSOR SURFACES USED IN ONLIMO TECHNOLOGY}

\author{
Muhammad Haqqiyuddin Robbani, and Heru Dwi Wahjono \\ Center for Environmental Technology, BPPT, Puspiptek Area, South Tangerang, 15314, Indonesia \\ E-mail: muhammad.haqqiyuddin@bppt.go.id ; heru.dwi@bppt.go.id
}

\begin{abstract}
One of the problems that arises during the process of implementing online monitoring technology (Onlimo) is the appearance of biofilms on the surface of the multiprobe sensor used. The presence of this biofilm can interfere with the sensor's performance in reading. Therefore we need an in-depth study of methods and technologies that can be used to prevent the appearance of biofilms on the sensor surface. This paper is compiled based on literature review and the results of research conducted by various universities and research institutions both outside and within the country, both on a laboratory scale, bench, or pilot-plant. Literature excavation includes the process of biofilm formation, identification of conventional biofilm formation prevention technologies, and identification of the latest biofilm formation prevention technologies. This paper is expected to be an information and reference material in choosing the right technology to be applied.
\end{abstract}

Keywords: biofilm, online monitoring, sensor, prevention technology 


\section{PENDAHULUAN}

\subsection{Latar Belakang}

Data Kementerian Lingkungan Hidup dan Kehutanan (KLHK) terkait rata-rata Indeks Kualitas Air (IKA) Nasional menunjukan penurunan sebesar $11 \%$ pada periode 20152017 (KLHK, 2018; KLHK, 2017). Data tersebut juga dapat diartikan sebagai adanya peningkatan beban pencemaran air pada Daerah Aliran Sungai (DAS) yang cukup siginifikan di tingkat Nasional. Pencemaran air pada DAS di Indonesia termasuk tinggi sehingga perlu mendapatkan perhatian secara serius. Masih rendahnya kesadaran penduduk dan pelaku usaha di sekitar DAS akan pentingnya menjaga kualitas air sungai serta minimnya fasilitas pemantauan dan pengendalian kualitas air secara realtime merupakan alasan utama tingginya angka pencemaran air sungai.

Minimnya fasilitas pemantauan dan pengendalian kualitas air sungai secara realtime ini disebabkan oleh kenyataan bahwa masih tingginya biaya yang harus dikeluarkan untuk mengaplikasikan teknologi telemetri. Tingginya biaya ini lantaran peralatan yang dibutuhkan seluruhnya masih diimpor. Biaya ini tentu dapat dihemat secara signifikan jika ketergantungan terhadap produk impor peralatan pemantauan dapat dikurangi. Hal ini dapat dicapai jika produksi peralatan teknologi telemetri dapat dilakukan di dalam negeri. Atau dengan kata lain, perlunya dilakukan riset pengembangan teknologi telemetri untuk kemudian dapat diproduksi dan diterapkan di Indonesia.

Sejak tahun 2014 hingga 2019 BPPT dan KLHK telah melakukan pengembangan dan penerapan teknologi online monitoring kualitas air berbasis telemetri dengan menggunakan multiprobe sensor di 15 DAS prioritas dan telah terpasang pula stasiun pemantauan kualitas air sungai dan danau di 16 lokasi di Indonesia (Wahjono, 2017; PPA, 2014). Salah satu permasalahan yang timbul selama proses penerapan teknologi online monitoring (Onlimo) adalah munculnya biofilm pada permukaan sensor multiprobe yang digunakan. Kehadiran biofilm ini dapat mengganggu performa sensor dalam melakukan pembacaan. Oleh karena itu diperlukan suatu kajian mendalam terkait metode dan teknologi yang dapat digunakan untuk mencegah munculnya biofilm pada permukaan sensor.

\subsection{Tujuan Penelitian}

Tujuan dari tulisan ini adalah untuk melakukan identifikasi terhadap metode dan teknologi pencegahan pembentukan biofilm di permukaan sensor yang digunakan pada teknologi Onlimo yang telah dilakukan dari penelitian skala laboratorium maupun yang telah diaplikasikan dalam skala industri. Tulisan ini diharapkan dapat menjadi informasi dan bahan rujukan dalam memilih teknologi yang tepat untuk diaplikasikan.

\section{BAHAN DAN METODE}

Tulisan ini disusun berdasarkan kajian literatur. Bahan diambil dari kajian literatur dan hasil riset yang dilakukan oleh berbagai universitas dan lembaga penelitian baik diluar maupun dalam negeri, baik dalam skala laboratrium, bench, ataupun pilot-plant. Penggalian literatur meliputi proses pembentukan biofilm, identifikasi teknologi pencegahan pembentukan biofilm secara konvensional, serta identifikasi teknologi pencegahan pembentukan biofilm terkini.

\section{HASIL DAN PEMBAHASAN}

\subsection{Pembentukan Biofilm}

Biofilm merupakan kumpulan sel mikroorganisme, khususnya bakteri, yang melekat di suatu permukaan dan diselimuti oleh pelekat karbohidrat yang dikeluarkan oleh bakteri (Lopez, 2010). Biofilm terbentuk karena mikroorganisme cenderung menciptakan lingkungan mikro dan relung (niche) mereka sendiri. Struktur dari suatu biofilm sangat tergantung dari lingkungan tempatnya berada, contohnya adalah kandungan nutrisi dan keadaan fisik (Prescott, 2002). Di alam, sangat jarang terdapat biofilm yang hanya terdiri dari satu spesies, biasanya biofilm tersusun dari beberapa spesies dalam lapisan-lapisan yang berbeda.

Biofilm sering didapati terbentuk pada hampir semua peralatan/bahan padat baik benda hidup maupun mati yang lembab ataupun tercelup cairan. Benda hidup misalnya gigi dan kulit hewan air, batang, akar, dan daun tumbuhan air, serta usus manusia. Benda mati misalnya peralatan medis, batu-batuan, partikel tanah, bagian bawah galangan kapal, pipa saluran air, dan benda lain yang tergenang air. Karakter lapisan berlendir pada biofilm dapat dirasakan dan dilihat dengan mata telanjang. Biofilm dapat tumbuh pada lingkungan ekstrim mulai dari lingkungan yang sangat asam sampai alkalin, sumber air panas, air asin, sampai ke daerah yang sangat dingin seperti di Antartika.

Satu komponen biofilm dapat terdiri dari berbagai jenis mikroba, seperti bakteri, archaea, protozoa, fungi, dan alga. Setiap jenis mempunyai peranan matabolik yang berbeda selama tahap pembentukan biofilm. Namun, kebanyakan biofilm terbentuk oleh sel dari spesies yang sama dibawah kondisi tertentu. Secara umum, faktor yang mempengaruhi pembentukan dan pertumbuhan biofilm antara 
lain: laju penetrasi nutrient, kelembaban lingkungan (terutama daerah permukaan benda), $\mathrm{pH}$, aerobisitas area dalam biofilm, tegangan permukaan, serta keheterogenan dan kehomogenan populasi (Beech, 2005).

Mikroba mengembangkan berbagai mekanisme untuk melekat pada suatu permukaan. Menurut Aparna dan Yadav (2008), perlekatan mikroba pada suatu permukaan dipengaruhi oleh kondisi lingkungan seperti perubahan nutrien, konsentrasi nutrien, $\mathrm{pH}$, temperatur, konsentrasi oksigen, osmolaritas, dan besi (Gambar 1.). Namun kondisi yang dibutuhkan berbeda untuk setiap jenis mikroba.

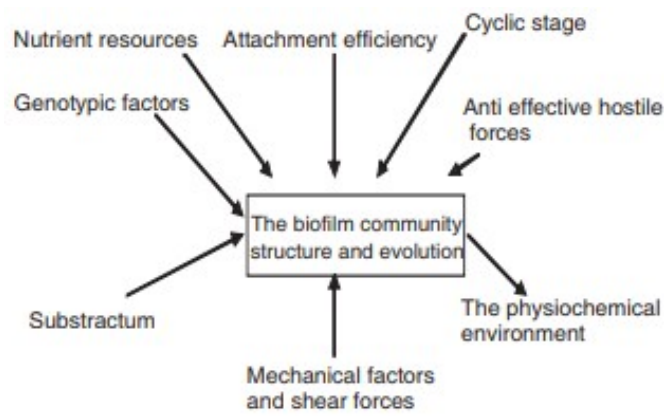

Gambar 1: Karakteristik lingkungan dan kultur yang mempengaruhi seleksi multispesies biofilm

Adapun jenis material permukaan sangat kecil bahkan tidak mempunyai efek terhadap pembentukan biofilm. Belum ditemukan mikroba yang tidak mampu membentuk biofilm pada material pipa apapun jenisnya. Mikroba mempunyai kemampuan adhesi yang sama pada semua jenis permukaan, seperti stainless steel, Teflon, PVC dan PVDF. Oleh sebab itu, kemampuan bakteri dalam menghasilkan berbagai jenis enzim, dalam hal ini ektoenzim dan ekternal enzim, merupakan faktor utama yang sangat penting dalam menginisiasi terbentuknya interaksi antara sel dan permukaan benda (Beech, 2005).

\subsection{Teknologi Pencegahan Pembentukan Biofilm Konvensional}

Perkembangan teknologi untuk membersihkan dan mencegah pembentukan biofilm telah banyak dilakukan. Teknologi konvensional yang paling banyak digunakan adalah dengan pemberian senyawa/larutan kimia sebagai desinfektan sebelum pembentukan biofilm terjadi. Akan tetapi, fase awal pembentukan biofilm (penempelan mikroba pada permukaan) merupakan proses yang cepat (kurang dari 1 jam), sehingga proses pemberian desinfektan ini sebenarnya tidak terlalu efektif mencegah pembentukan biofilm (Das, 1998). Dapat dilihat di Gambar 2, grafik pertumbuhan bakteri setiap jamnya.

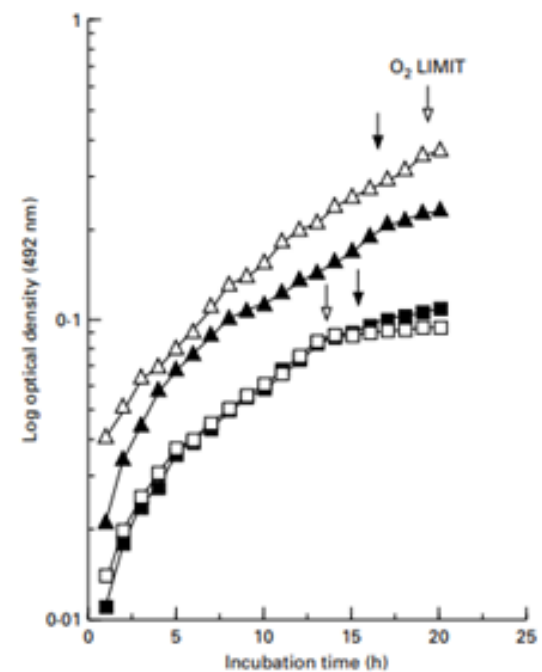

Fig. 2 Development of Staphylocerass epidermidis biofilm ( $\mathbf{D}$ ) and growth of planktonic coemponent $(\mathbf{\Delta})$ in microtitre wellk. Data for

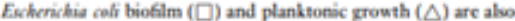
shown. Arrows indicate the oescet of saticenary phase in each compartment due to oxygen limitation

Gambar 2: Pertumbuhan bakteri setiap jam (Das dkk., 1998)

Teknologi pembersih lainnya yang umum digunakan adalah biosida. Dapat dilihat pada Tabel 1. urutan kekuatan biosida yang umum digunakan untuk membersihkan biofilm. Kebanyakan larutan yang digunakan merupakan senyawa oksidator yang mampu memutus jaringan ekstraselular dari bakteri pembentuk biofilm. Enzim dan deterjen juga seringkali digunakan untuk meningkatkan efisiensi desinfektan dan biosida. Akan tetapi, biosida hanya efektif digunakan untuk membersihkan biofilm yang telah terbentuk, bukan mencegah pembentukan biofilm.

Tabel 1. Peringkat biosida dalam hal anti-bakteri biofilm (Meyer, 2003)

\begin{tabular}{ll}
\hline Biocide performance & Active ingredient \\
\hline Best & Peroxo acids \\
& Iodophores \\
& Biguanides \\
& Chlorine \\
& Amphoterics \\
Worst & Quarternary ammonium compounds \\
\hline
\end{tabular}

Teknologi pembersih secara mekanik/fisik juga telah banyak dikembangkan. Diantaranya teknologi scrubber (pembersih tekanan tinggi), dan teknologi busa (foam) dengan aliran vertikal atau turbulen dalam sistem tertutup. Penggabungan teknologi mekanik dengan teknologi biosida mampu meningkatkan efisiensi pembersihan hingga 99,7\% (Meyer, 2003). Akan tetapi, teknologi mekanik/fisik masih juga belum mampu mencegah pembentukan biofilm, karena pada prinsipnya teknologi mekanik/fisik hanya melepaskan ikatan antara bakteri dengan 
permukaan bahan, bukan membunuh bakteri tersebut secara permanen.

\subsection{Teknologi Pencegahan Pembentukan Biofilm Terkini \\ Selain teknologi konvensional,} dikembangkan pula teknologi terkini untuk mencegah dan membersihkan biofilm antara lain teknologi rekayasa bahan, teknologi ultraviolet, dan teknologi ultrasonic. Rekayasa bahan untuk mencegah pertumbuhan biofilm telah dilakukan sejak tahun 1983. Coating atau pelapisan permukaan bahan dengan biosida menjadi salah satu teknologi rekayasa bahan yang paling banyak digunakan. Beberapa peneliti telah mencoba menggunakan coating perak, kombinasi perak/klorheksidin, dan kombinasi klorheksidin/klorosienon. Akan tetapi, tidak ditemukan penurunan laju infeksi dari biofim secara signifikan. Secara prinsip biosida hanya mencegah pembentukan biofilm dengan melepaskan ikatan bakteri secara kimia, bukan membunuhnya. Penggunaan air yang sangat murni (ultra-pure water) pun didapat mampu mendorong pembentukan biofilm (Meyer, 2003).

Penggunaan nanopartikel untuk mencegah pertumbuhan bakteri penyebab biofilm juga telah dikembangkan selama beberapa dekade terakhir. Nanopartikel seperti kitosan, PLGA, silika, liposom, perak, emas, besi, tembaga, dan titanium sering digunakan untuk mencegah pertumbuhan bakteri (Han, 2017). Integrasi nanopartikel dengan bahan dapat mencegah proses adhesi bakteri dan pembentukan biofilm. Nanopartikel dapat ditanamkan dalam bahan maupun diaplikaskan dengan cara pelapisan. Akan tetapi masih dibutuhkan investigasi lebih lanjut mengenai nanopartikel, seperti mekanisme pembunuhan bakteri, kemungkinan terjadinya agregasi, isu kesehatan, dan masih banyak yang lainnya (Lee, 2018). Selain itu, biaya yang relatif mahal juga menjadi kekurangan dari teknologi ini.

Karena keterbatasan dan ketidakefektifan teknologi mekanik dan kimia, juga untuk mereduksi biaya, telah dikembangkan suatu teknologi pencegah pembentukan biofilm berbasis irradiasi sinar Ultra-Violet (UV). Meskipun teknologi UV sebenarnya telah lama ditemukan, akan tetapi dikarenakan kandungan merkuri dalam lampu UV tradisional, serta membutuhkan energy yang besar, maka dewasa ini telah dikembangkan lampu UV berjenis LEDs yang lebih ramah lingkungan. Keunggulan dari teknologi ini antara lain: non-toksik, bekas jejak yang ditinggalkan rendah, daya yang dibutuhkan rendah (dibandingkan teknologi UV yang lama), dan dapan digunakan dalam siklus lifetime yang optimal (CISUVS, 2018). Menurut Lakretz, dkk $(2009,2011)$, rentang panjang gelombang 254 $270 \mathrm{~nm}$ merupakan panjang gelombang yang paling efektif dalam inaktivasi bakteri pembentuk biofouling.

Teknologi UV dapat dikombinasikan dengan teknologi Advanced Oxidation Process (UVbased AOP). Dengan memanfaatkan MediumPressure UV light dan hydrogen peroksida, teknologi UV-based AOP menunjukan potensi yang lebih tinggi dalam mencegah pertumbuhan bakteri biofilm bila dibandingkan dengan penggunaan kedua teknologi tersebut secara terpisah (Lakretz, 2011). Kombinasi UV dengan biosida juga telah dikembangkan pada akhir dekade ini. Mao dkk (Mao, 2017) melaporkan adanya penurunan jumlah bakteri yang tumbuh pada membran yang telah dilapisi Antimicrobial peptides (AMPs) dan disinari UV pada panjang gelombang $360 \mathrm{~nm}$ selama 15 menit. Teknologi UV (baik dikombinasikan maupun tidak) memang menjanjikan kelebihan dalam hal pencegahan bakteri dalam membentuk biofilm. Hanya saja, waktu yang diperlukan untuk membunuh bakteri secara efektif relatif lama yakni sekitar 21 jam (Lakretz, 2009). Selain itu paparan sinar UV dalam jangka panjang juga berakibat kurang baik bagi kesehatan manusia.

Pencegahan pembentukan biofilm menggunakan teknologi ultrasound juga telah dikembangkan secara serius dalam beberapa dekade terakhir. Ultrasound merupakan salah satu pengembangan metode mekanik dalam pencegahan biofilm (Zbeda, 2017). Lambert, dkk. (2010) melaporkan efektifitas ultrasound dalam membersihkan biofilm hampir sama dengan teknologi UV dan biosida namun dengan biaya dan energi yang lebih besar dibanding keduanya apabila dibangun dalam skala pilot plant. Menurutnya, teknologi ultrasound mempunyai keterbaatasan yakni harus bersentuhan langsung dengan bakteri untuk dapat membunuhnya secara maksimal. Sementara Oder, dkk (2017) menemukan bahwa teknologi ultrasound dapat memberikan dampak yang lebih signifikan dalam pencegahan pembentukan biofilm apabila dikombinasikan dengan teknologi biosida. Salah satu perkembangan terkini dari teknologi pencegah biofilm berbasis ultrasound yang digunakan pada sensor pengamat kualitas air adalah teknologi cleaning yang dikembangkan oleh WTW, produsen sensor asal jerman. Teknologi yang dikembangkan adalah ultrasound generator berukuran kecil yang terintegrasi didalam sensor. WTW mengklaim teknologi ini mampu membersihkan permukaan sensor dalam waktu singkat dan meningkatkan ketelitian pengukuran sensor (XAGS, 2019).

\section{KESIMPULAN}

Dari semua opsi teknologi pembersih dan pencegah biofilm yang telah dikembangkan, teknologi kombinasi ultrasound dengan biosida 
menunjukkan keunggulan dibandingkan dengan semua teknologi yang ada. Akan tetapi efektifitas dan efisiensi teknologi tersebut belum pernah diujikan pada sensor yang digunakan dalam teknologi onlimo. sehingga penelitian lebih lanjut mengenai efesiensi dan efektifitas teknologi ultrasound, biosida, maupun kombinasi keduanya, sangat penting untuk dilakukan.

\section{PERSANTUNAN}

Penulis menyampaikan ucapan terima kasih kepada Troika PPTL yang telah mengarahkan dan membiayai penelitian ini. Tidak lupa ucapan terimakasih kepada rekan-rekan tim Onlimo yang telah membantu dalam melaksanakan kegiatan litbang untuk mendukung penerapan teknologi online monitoring kualitas air secara online dan realtime di sungai tercemar di Indonesia.

\section{DAFTAR PUSTAKA}

1. Kementerian Lingkungan Hidup dan kehutanan RI (2018). Indeks Kualitas Lingkungan Hidup Indonesia 2017. Pusat Data dan Informasi KLHK RI.

2. Kementerian Lingkungan Hidup dan kehutanan RI (2017). Indeks Kualitas Lingkungan Hidup Indonesia 2016. Pusat Data dan Informasi KLHK RI.

3. Wahjono, H. D. (2017). Pengembangan Sistem Sampling Air untuk Mengatasi Gangguan Lumpur pada Sistem Online Monitoring Kualitas Air Sungai. Jurnal Teknologi Lingkungan, 20(1), 113-122.

4. Direktorat PPA. (2014). Database Perhitungan Meningkatnya Kualitas Air Sungai di 15 DAS Prioritas. Kementerian Lingkungan Hidup dan Kehutanan (KLHK).

5. López, D., Vlamakis, H., \& Kolter, R. (2010). Biofilms. Cold Spring Harbor perspectives in biology, 2(7), a000398.

6. Prescott, L. M., Harley, J., \& Klein, D. (2002). Normal microbiota and nonspecific host resistance. Microbiology, 5.

7. Beech, I. B., Sunner, J. A., \& Hiraoka, K. (2005). Microbe-surface interactions in biofouling and biocorrosion processes. International microbiology, 8(3), 157-168.

8. Aparna, M. S., \& Yadav, S. (2008). Biofilms: microbes and disease. Brazilian Journal of Infectious Diseases, 12(6), 526-530.

9. Das, J. R., Bhakoo, M., Jones, M. V., \& Gilbert, P. (1998). Changes in the biocide susceptibility of Staphylococcus epidermidis and Escherichia coli cells associated with rapid attachment to plastic surfaces. Journal of applied microbiology, 84(5), 852-858.
10. Meyer, B. (2003). Approaches to prevention, removal and killing of biofilms. International Biodeterioration \& Biodegradation, 51(4), 249253.

11. Han, C., Romero, N., Fischer, S., Dookran, J., Berger, A., \& Doiron, A. L. (2017). Recent developments in the use of nanoparticles for treatment of biofilms. Nanotechnology Reviews, 6(5), 383-404.

12. Lee, D., Seo, Y., Khan, M. S., Hwang, J., Jo, Y., Son, J., ... \& Choi, J. (2018). Use of nanoscale materials for the effective prevention and extermination of bacterial biofilms. Biotechnology and Bioprocess Engineering, 1-10.

13. CISUVC. (2018). Biofilm Prevention. http://www.cisuvc.com/applications/industrial/ biofilm-prevention.

14. Lakretz, A., Ron, E. Z., \& Mamane, H. (2009). Biofouling control in water by various UVC wavelengths and doses. Biofouling, 26(3), 257-267.

15. Lakretz, A., Ron, E. Z., \& Mamane, H. (2011). Biofilm control in water by a UV-based advanced oxidation process. Biofouling, 27(3), 295-307.

16. Mao, C., Mohanraj, G., Kandiyote, N. S., Kasher, R., \& Arnusch, C. J. (2017). UV mediated attachment of short ArginineTryptophan antimicrobial peptides on reverse osmosis membrane surfaces inhibit Pseudomonas aeruginosa biofilm. Desalination.

17.Zbeda, R. M., \& Cooper, H. J. (2017). Biofilms on orthopedic implants: novel strategies for detection and prevention. MINERVA ORTOPEDICA E TRAUMATOLOGICA, 68(2), 51-57.

18. Lambert, N., Rediers, H., Hulsmans, A., Joris, K., Declerck, P., De Laedt, Y., \& Liers, S. (2010). Evaluation of ultrasound technology for the disinfection of process water and the prevention of biofilm formation in a pilot plant. Water Science and Technology, 61(5), 1089-1096.

19. Oder, M., Stra啪ar, E., \& Filip, S. (2017). Efficacy of cleaning methods for the removal of Bacillus cereus biofilm from polyurethane conveyor belts in bakeries. Food Control, 80, 267-272.

20.Xylem Analytics Germany Sales. (2019) https://www.wtw.com/en/products/productcategories/sensor-technology/digital-iqsensors-online/iq-optical-spectral-probes-uvvis-for-carbon-parameters-and-suspendedsolids 